\title{
Choosing The Road Less Traveled: Alternatives to the Tenure Track
}

\author{
Lisa Bullard, Penny Knoll, Ann Saterbak \\ North Carolina State University / Montana State University / Rice University
}

\begin{abstract}
Tenure has been traditionally held up as the "Holy Grail" for those in academia -- however, some new faculty make a conscious choice to pursue non-traditional academic roles. In this paper, three new engineering educators relate how their interests, priorities, and family situations led them to seek out non-tenure track faculty positions and candidly discuss the benefits as well as the drawbacks of the paths they have taken. The objective of the paper is to help both prospective and current faculty become aware of the non-tenure track role as a valid and rewarding career path.

Introduction
\end{abstract}

A recent study done for the 16-campus University of North Carolina system indicated that North Carolina's public universities are hiring an increasing number of part-time and non-tenured instructors to teach undergraduates. "The portion of teaching positions filled by part-time, retired, and other non-tenure instructors grew from $25 \%$ in 1996-97 to 33\% in 1999-2000, and their share of the teaching load grew from 36\% to 43\%." 1 In Australia, surveys suggest that one in six university teachers is now a part-time instructor, referred to as a "casual." 2 At Rice University, while $92 \%$ of the 481 full-time faculty are tenured or tenure-track, an additional 144 individuals are employed in part-time positions ${ }^{3}$.

One might draw several different conclusions from these observations. A cynical view might be that budget shortfalls are forcing tenured faculty to spend more time on proposal writing and grant solicitation and less time on teaching, requiring additional non-tenured faculty to pick up the slack. As a result, students are shortchanged by having less qualified and less experienced personnel in the classroom. A more realistic perspective may be that these types of non-tenured positions are attractive and offer several advantages to those seeking a more flexible position in academia. Furthermore, those seeking such positions may be more focused on undergraduates and motivated to share their life experience with the students.

Why might someone pursue this type of position? How do they feel about it after a few years serving in this role? Is a tenured position an eventual goal? Should it be? This paper will explore the perspectives of three engineering faculty members who have made this career choice.

Faculty Perspectives 
Faculty Member \# 1. The first faculty member is 38 years old and graduated with B.S. in Chemical Engineering in 1986 and a PhD in Chemical Engineering in 1991. She joined Eastman Chemical Company in 1991 and served in various engineering and management positions within the company, including Process Engineering, Plant Engineering, Quality Management, Business Process Improvement, and Business Market Manager for Food Ingredients and Personal Care Products. She returned to her alma mater, N.C. State, in April, 2000 as a Visiting Assistant Professor and Coordinator of Undergraduate Advising. She has taught the introductory sophomore material and energy balance courses as well as the senior design sequence and has served on multiple departmental and university committees. She has been married for 12 years, and her husband is a civil engineer who works for a consulting firm in Raleigh. They have a sixyear-old daughter.

Why did you pursue a non-tenured academic position? "When I started graduate school, academia was a definite goal. By the time I finished, I realized that I didn't have the passion for research that I saw in my advisor and other faculty. Besides, the idea of teaching the principles of chemical process design while never having designed anything real seemed ludicrous. My husband and I were both fortunate to secure positions as engineers at Eastman Chemical Company in Kingsport, Tennessee.

Leaving industry to return to academia was a difficult decision. My husband and I had both worked for Eastman for almost 10 years. While I had multiple options as a chemical engineer in a large company, my husband's career opportunities as a civil engineer were limited to either wastewater treatment or environmental affairs. In addition, the company was going through some difficult business conditions, and we questioned whether having both careers tied up in one company was wise. Finally, both our families were in North Carolina, and the prospect of being a state away from aging parents concerned us. My last position at Eastman, as a Business Market Manager, required extensive travel and overtime. With a small child and other interests outside of work, the demands were becoming too great to balance.

I had maintained a good relationship with the Chemical Engineering Department at N.C. State since graduation. As I started to explore career options, I realized that my most fulfilling roles at Eastman involved coaching and development of other personnel. When the department's coordinator of undergraduate advising announced his retirement plans, I pursued the position and was named as his replacement. I was fortunate that he stayed on for seven more months to train me in the role. During this time, I taught two new classes and worked closely in parallel with him to learn the advising process."

How do you feel about the position now? "After two years in the position, I've finally established my roles and responsibilities as part of the faculty and feel accepted by the department. My three predecessors in the coordinator's role were full professors who "evolved" into the position at the end of their careers, and I think I was viewed with some uncertainty as a younger person coming into it early in her career. My title is still "Visiting Assistant Professor" -- which causes my undergraduate advisees to ask me continually if I am planning to stay. My contract is renewed every six months. It's not a "permanent" position in a contractual sense -but my department head has assured me that I have the position for as long as I want it. 
In my first few months at N.C. State, I became the de facto "departmental committee member," serving on the Coordinators of Advising, Course and Curriculum, and ABET Committees, and any other committee which needed a representative from the department. While I still assume most of the administrative responsibilities related to the undergraduate curriculum, the position has developed into one jointly focused on undergraduate teaching (particularly in the design area) and undergraduate advising. I have participated to a modest level in proposal and paper writing in the area of educational scholarship, but I anticipate that this will always take a back seat to having direct student contact in the classroom and in an advising setting, which is the most fulfilling part of my job. In my industrial position, making a difference meant influencing sales and earnings; in this one, it means affecting the lives of students I meet, which is far more satisfying."

Will you ever pursue a tenure track position? "At this point, I have no inclination to earn tenure. After observing the tenure-track personnel in my own department and at other institutions, I once again conclude that I don't have the passion for research that would inspire me to take on the proposal writing, publication pressures, and graduate student supervision required to be successful. One of my colleagues ruefully observed that 'he spent only 3 or 4 nights a month with his young children....but that he would make it up to them this summer.' For me, that lifestyle is not realistic. Finally, my department already has 25 tenured or tenure-track personnel who have a research focus - what we really need is at least one faculty member who has the time, energy, and desire to focus on undergraduate students."

Faculty Member \#2. The second faculty member is 38 years old and graduated with a B.S. in Construction in 1995 and an M.S. in Construction Management in 1999. She joined the Civil Engineering Department at Montana State University in 2000 as an Adjunct Instructor in Construction Engineering Technology (CET). She teaches both undergraduate and graduate classes; advises 45 undergraduate CET students; serves as the Director of the Internship program at MSU for both Civil and Construction Engineering students; and coordinates the biennial Construction Recognition dinner for MSU, at which the university recognizes the outstanding construction personnel in the State of Montana and hosts over 400 contractors and employees. Prior to joining the university, she spent 11 years in construction in Phoenix, Arizona with various employers. Seven of those years were spent as an owner of a design-build commercial contracting firm. She has been married for 9 years, and her husband is retired and works as a sculptor.

Why did you pursue a non-tenured academic position? "During my undergraduate education (and graduate education), I was working full time in the construction industry and attending classes part-time ( 9 to 12 hours per semester). At times, I felt that my practical knowledge of actual field work was not being expressed as clearly in the classroom as it could have been.

Planning has always been a very large part of my personal and business methods. In 2000, my husband and I decided that we would retire our design-build firm, and he would enter into retirement. Since my husband is 17 years my senior, I did not want to retire, but chose to enter academia to teach my life experiences. This is the reason I returned to get my master's degree in 1997 to 1999. 
There was only one construction school I was pursuing -- Montana State University. Since 1997, I would take every opportunity to visit with the Director of the Program. In early 1999, both instructors in the CET program were retiring, and I applied to the national search and was chosen as one of two new faculty members at MSU to start January 2000.”

How do you feel about the position now? "After two years of teaching, I love my job and truly enjoy interacting with the students, since they really are the future. I have a great amount of influence shaping the future of the construction industry through my students. I think in this field of academics (construction), you have to be a practitioner before you can be an instructor. The students are truly smart enough to know when a professor has been there and done that or just read it in a book. It's all about credibility. This industry is an industry that is truly tough as nails, and typically the students are too. They will NOT respect you if you have not been there and done it in reality."

Will you ever pursue a tenure track position? "I doubt it. I can understand its appeal -- the fact that after you have made it, you are set for life -- but should that really be the way academics is practiced? If a medical doctor only cared about the fact that licensing was the most critical part of their career, then we would not be as advanced in U.S. medicine as we are. I would rather be a yearly contracted employee knowing that my students are truly learning and appreciating my sharing of knowledge, then worry about the deadline for my next journal article.

If we could change academics where we could have true researchers and true practicing teachers, I think the U.S. college education would far pass that of any European or Asian college education. Lech Walesa said it best in my opinion: 'The U.S. is the last remaining supreme power, and we have a choice: take the center stage and lead the way or get out of the way and let some other country do it for us.' I would like to see the U.S. take the lead in ALL matters as the last remaining super power and change the way college academics is done. Let's provide a balance between teaching and research and allow those who are great at teaching be reinforced for their contribution to the department."

Faculty Member \#3. The third faculty member is 33 years old and graduated with B.A. in Chemical Engineering and Biochemistry in 1990 and a Ph.D. in Chemical Engineering in 1995. She joined Shell Development Company in 1995 and worked at the Research and Development Center in the Environmental Division. She worked on a number of technical projects, including land treatment, wastewater treatment, ecological risk assessment, and biodegradation and returned to her alma mater, Rice University, in March of 1999 to join the newly developed Bioengineering Department. She has developed the course materials for and has taught the introductory sophomore course entitled Conservation Principles in Biology and Medicine, as well as two laboratory courses: Lab Module in Tissue Culture and Advanced Bioengineering Laboratory. She also serves as an active member on the Undergraduate Committee and participates heavily in ABET-related activities. Recently, she was reclassified as faculty with the title, Director of Laboratory Instruction and Lecturer. She has been married for 5 years, and her husband is a chemical engineer who works for Shell Chemicals in Houston. They have a two year old daughter.

Proceedings of the 2002 American Society for Engineering Education Annual Conference \& Exposition Copyright@ 2002, American Society for Engineering Education 
Why did you pursue a non-tenured academic position? "I went to graduate school because I wanted to teach at the college level. What I didn't appreciate at the time was the emphasis placed on research in engineering faculty jobs. I quickly discovered that the research/teaching balance and the hours required to be "successful" in most tenure-track jobs were not for me. My technical interests had always been biomedical engineering; however a hiring slow-down in the biotech and pharmaceutical industry the year I graduated left me with no good choices in that area. My husband and I were both very fortunate to find jobs at the Shell R\&D Center in Houston. I easily transitioned into a job that was mostly chemical engineering but did include some biology.

While I was happy enough at Shell, I still wanted to teach. Living in Houston enabled me to cultivate relationships with faculty in the Chemical Engineering department at Rice University. At times, I went out of my way to run into these individuals, saying, "If there is ever a job that is just teaching, please give me a call." Usually, I was rebuffed. In 1997, the Bioengineering Department was created, and five faculty members moved over from the Chemical Engineering Department. The faculty drew up ambitious plans for undergraduate and graduate programs in Bioengineering. As they considered all the courses that needed to be developed and taught, the idea of a non-tenure track person willing to develop courses and teach looked appealing. So, I got the call. In a nutshell, I was in the right place at the right time.

A non-tenure track academic position offers many obvious advantages: a flexible schedule, the opportunity to work with very bright and motivated students, being on a college campus, etc. In addition, many of the disadvantages I perceive in a tenure-track job such as publishing research articles, writing grants, and the pressure of tenure are not present."

How do you feel about the position now? "I love my job. My job is well suited to my strengths and personality. I love working with the bright and highly motivated students at Rice University. I teach students in our program in their sophomore, junior, and senior years. Since our classes are small (20-35 students) and I choose to be in the lab all afternoon with the students, I really get to know the students. I derive great pleasure from seeing the students learn, have an "ah ha" moment, improve their oral presentation skills, build their confidence, discover their interests in bioengineering, and more.

I am in a department that supports and appreciates my contributions as a teacher. Rarely am I treated as a "second-class citizen." In fact, several of my colleagues urged me and then badgered the department head to reclassify my position from staff to faculty. I try to reserve my strong opinions to issues that directly impact the undergraduate students. As a result, I believe that I am respected and not seen as overstepping my bounds as a non-tenure-track faculty member.

The flexible nature of my job has been a blessing. My daughter Miriam was born in April, 2000 and has Down syndrome. At birth, she had a few serious medical problems; in addition, she has some developmental delays. Currently, I stay home two mornings a week. Together with my husband's part-time employment and my mother's commitment to caring for her two mornings a week, we are able to keep her at home. I still work my full 40 hours (or more) each week, but the flexibility has enabled us to work out a schedule that we feel is best for my daughter." 
Will you ever pursue a tenure-track position? "At the end of the most intense laboratory course I teach, one student asked me, 'How will you ever get tenure when you spend so much time with us?' I explained that I did not do research and thus could devote most of my time to teaching. I also explained that I will never get tenure unless the criteria for tenure at Rice University changes. Some days I think I should get tenure for my contributions in bioengineering education, and maybe at another university it could happen. Together with two colleagues, I have a contract with Prentice Hall to develop the content of the sophomore Bioengineering course into a textbook. In addition, I have developed and written four new laboratory modules (each 2 to 6 weeks in length) focused on bioengineering at the cellular and molecular level. I expect to publish these modules on the web in 2002-03. I am not disappointed, though, that I will probably never get tenure, as I never expected it when I took this job. My passion is teaching, not research. I will stick to jobs that focus on teaching - with or without tenure."

\section{Discussion}

Though the backgrounds and life situations of these three faculty members are very different, there are some common themes in their experience:

- The desire to interact with undergraduate students and influence undergraduate education. Each faculty member has a desire to interact with undergraduates and share their engineering experience in the classroom and/or the laboratory. Each faculty member truly enjoys the one-on-one interaction with the students and derives job satisfaction from interacting with and mentoring students.

- The desire for additional job flexibility. All three individuals had previously worked in industry or consulting and were seeking positions that were more compatible with their family situations and priorities. While the number of hours worked may not be less (in fact, it may be more), the relative flexibility of the position was attractive for them. Depending on whether the position is a 9-month or 12-month role, the summer may be available, providing additional discretionary time.

- The risk in being viewed as the "volunteer" for all departmental service. Other tenured or tenure-track professors may breathe a sigh of relief when a new, non-tenured person joins the department: "Finally, someone to whom I can pawn off Course and Curriculum and ABET Committees!" It is easy for the new non-tenured professional, eager to make a good impression, to agree to serve as the departmental representative on an ever-growing number of committees and task forces.

While untenured faculty may in fact assume a larger administrative role later in his or her career (such as Assistant Department Head), it is wise to limit committee assignments if possible initially. The new non-tenured professional should document time spent on committee work, teaching, and advising so that the department head can fairly distribute such service assignments. One drawback of having a relatively new, non-tenured person, serve on high-stakes teams such as ABET is that this individual may have little leverage to persuade the rest of the faculty to engage in additional work required by accreditation and other curriculum reexamination processes.

Proceedings of the 2002 American Society for Engineering Education Annual Conference \& Exposition

Copyright $\odot$ 2002, American Society for Engineering Education 
- The trade-offs in pay, title, and respect. While traditionally many full professors have taken on the responsibilities of undergraduate advising, laboratory coordination, undergraduate teaching, etc. at the end of their careers, someone who enters such roles early in his or her career will likely come in as a Lecturer, Instructor, or "Visiting _ ", particularly at a research institution. To someone coming from industry in particular, the cut in pay may come as a shock. Within the university system, an unspoken but understood hierarchy exists, and someone without the word "Professor" in his or her title may be looked on as a secondclass citizen. Other tenured or tenure-track professionals may not understand why someone would deliberately choose a non-tenured position unless he or she had failed in their pursuit of tenure.

- The value of industrial experience. Each of these individuals had worked in industry for periods ranging from five to eleven years and brought their experience to their new jobs. Their industrial background may have been seen as an asset to the department and made them more attractive candidates than new Ph.D.'s coming straight out of graduate school. In addition, their experience may have allowed them to negotiate for a higher starting salary than a new Ph.D. graduate could command.

- The importance of maintaining contacts within the engineering community. Two of the three individuals replaced retiring personnel, and one joined a newly formed department. Two of them returned to their B.S. alma mater. Each mentioned the importance of maintaining contacts with their undergraduate or graduate departments, or in the case of Faculty Member \#2, a department with a strong program in her area. Faculty Member \#3 repeatedly asked for her job before it was even created. Persistence and networking are required to find out about potential positions and then to secure them.

- The importance of being secure in the role. The three subjects of this paper deliberately pursued and chose their non-tenured role because of their strengths, interests, and lifestyle preferences. They are confident and secure in their career interests and desires. None are using their position as a "back door" entry point to a tenure position. This confidence may help minimize and deflect some negative bias towards non-tenure track positions. In fact, former industrial colleagues have expressed envy of their positions, saying, "You are so lucky to be able to teach at a university without having to do research!"

\section{Conclusions}

A non-tenured faculty position in an engineering department is not for everyone. It is important that the potential faculty member have a realistic view of the trade-offs involved, such as potentially lower pay, a title that may not include the word "professor", and additional departmental and university service requirements. However, for those persons seeking a more flexible academic position without the additional hurdle of the tenure process, it can be a satisfying way to contribute to undergraduate education, share one's industrial experience with students, and influence the direction of the department. As non-tenured academics successfully establish themselves within engineering departments, universities will hopefully become more 
receptive to the idea of non-tenured professionals returning to teach and advise students, and engineering professionals will increasingly consider second careers in academia.

\section{Postscript}

The three faculty members in this paper have each been in academia for 2-3 years. At this point the biggest unknown is the long-term satisfaction in and evolution of their non-traditional academic roles. Each has been asked by research-focused colleagues, "Don't you think you'll get bored?" Although the authors doubt it, it remains to be seen...stay tuned for a future update as they mature in their roles.

\section{References}

[1] Jane Stancill, "Is Tenured Teaching Off Track at UNC?," The News \& Observer, March 8, 2001.

[2] "Education on the Casual Side," ASEE Prism, September, 2001, p. 11.

[3] Rice University Fact Sheet, Office of Institutional Research at Rice University, November 2001.

\section{LISA BULLARD}

Lisa G. Bullard received her B.S. in Chemical Engineering from North Carolina State University in 1986 and her $\mathrm{PhD}$ in Chemical Engineering from Carnegie Mellon University in 1991. She joined Eastman Chemical Company in 1991 and served in various engineering and management positions within the company. She returned to her alma mater, N.C. State, in 2000 as a Visiting Assistant Professor and Coordinator of Undergraduate Advising.

\section{PENNY KNOLL}

Penny M. Knoll joined the Department of Civil Engineering at Montana State University in 2000 as an Adjunct Instructor in Construction Engineering Technology (CET). She received her Bachelor of Science in Construction from Arizona State University in 1995 and her Master of Science in Construction Management from Arizona State University in 1999.

\section{ANN SATERBAK}

Ann Saterbak is Director of Laboratory Instruction and Lecturer in the Bioengineering Department at Rice University. She received her B.A. in Chemical Engineering and Biochemistry from Rice University in 1990 and her $\mathrm{Ph} . \mathrm{D}$. in Chemical Engineering from the University of Illinois in Urbana-Champaign in 1995. She conducted research and provided technical support within Shell Development Company from 1995 to 1999. 